\title{
Structuring German postwar ideologies: review of A. Dirk Moses, German intellectuals and the Nazi past
}

Cambridge: Cambridge University Press, 2007

\author{
Noah B. Strote
}

Published online: 11 December 2008

(C) The Author(s) 2008. This article is published with open access at Springerlink.com

It is not only because much of the ideological landscape of postwar West Germany remains - to borrow one historian's metaphor - "uncharted intellectual territory" that German Intellectuals and the Nazi Past comes as such a key contribution to the historiography of twentieth-century thought. To be sure, while certain canonized figures, such as Jürgen Habermas, Günter Grass, Hans-Georg Gadamer, Karl Jaspers, and even the psychoanalysts Alexander and Margarete Mitscherlich have received adequate attention in Anglophone scholarship, we have precious few studies in English on many of the thinkers examined here by Moses. These are the lesser-known postwar "historians, philosophers, sociologists, political scientists, and educationalists" (p. 10) who served on government advisory committees, became ministers of culture and education, or in other ways decisively shaped the political discourse of the Federal Republic. For that reason alone Moses was guaranteed to cover new ground. But it is ultimately the innovative way in which he has mapped his subject matter that makes this work stand out, not only as an indispensable guide to early debates about Nazism and West German democracy, but more generally as a distinctively original model for writing about intellectuals and their ideas.

"This book is not a conventional intellectual history," we are told in the introduction (p. 10). Part of what makes that statement true is the attention Moses pays to fields that is all too often terra incognita for intellectual historians - namely, structural anthropology and the voluminous but neglected literature on German social psychology. His case for integrating research on family life, transgenerational transmission, and the like into a history of intellectuals rests on the deceptively profound insight that political ideas and ideologies, arguably nowhere more so than in postwar Germany, often possess "existential" significance for their articulators. Drawing on Erving Goffman's theories of social drama, Moses presents the political

\footnotetext{
N. B. Strote $(\bowtie)$

2521 19th Street, San Francisco, CA 94110, USA

e-mail: noah.strote@gmail.com
}

\section{N. B. Strote}

Department of History, University of California, Berkeley, CA, USA 
stances that West German intellectuals assumed in adulthood "as stagings of their personal histories" and more specifically as reflections of the identities they developed during adolescence in relation to the group (family and nation) (p. 10).

The origins of Habermas's moralizing left-liberalism and wholesale rejection of the German nationalist tradition are thus located in his and his friends' obligation "to direct their libidinal energies elsewhere" (p. 76) after their shocking realization as adolescents that "everything was false" in which they had believed as Nazi youths (p. 108). Likewise, the conservatism of political scientist Wilhelm Hennis in the 1950s and 1960s is traced back to his and his family's lack of identification with the Nazi regime as a teenager in the 1930s. To Moses, it is crucial that, unlike Habermas, Hennis's "political world did not collapse" in 1945, so that "he felt morally intact as an individual and as a patriotic German" (p. 75). Granted, to argue that the germs of political ideas reside in the early psychological life of thinkers is nothing new - it is one of the founding principles of psychohistory — but rarely is the argument extended so productively to the study of an entire generation, indeed multiple generations, of intellectuals. If Moses's strategy of unmasking ideology as identity at times flirts with oversimplification, it serves the more important purpose of bringing crucial structural elements of German postwar thought into the focus of analysis.

Moses's study itself follows an elegant structure. First, he identifies his subjects and locates their common trauma; he then goes on to analyze two opposite emotional responses to this trauma; next, he shows how these responses in turn determined the poles of right-left political discourse; and finally, he traces the development of this discourse from the foundation of the Federal Republic in 1949, to debates about university reform in the $1950 \mathrm{~s}$, to the political scandals and student movements of the 1960s, to the memory debates of the 1980s and 1990s. (The 1970s fall through the cracks, as they so often do.) An ambitious project, to say the least, but one that Moses executes in a judicious 283 pages without giving short shrift to his topic - a praiseworthy feat.

The subjects of the study consist of the three postwar generations of intellectuals beginning with those whom he calls the "1945ers." Born between 1922 and 1932, the '45ers lived through German defeat as young adults. As former Hitlerjugend, they felt the sting of the world's condemnation after the war. Hopes for a rehabilitated Germany were pinned squarely on this generation's "reeducation," which the international press monitored closely. Considering the power of the microscope under which the '45ers were placed, Moses sees their central traumatic experience as being, simply put, the "stigma" of being German after the Holocaust. Feeling that they had committed no crimes themselves, many young Germans could avoid feeling individual guilt for their country's recent past, but the stigmatized social identity imposed on them by non-Germans was inescapable. This trauma, Moses tells us, complicated their sense of "we-ness" (p. 33).

Moses proceeds to trace the emotions produced in these young people by the antiGerman stigma. Alongside shame, Moses points to the emotion of "indignation" (p. 30): indignation directed either toward their nation for bearing responsibility for the crimes that caused the stigma, or toward the rest of the world for making them feel guilty simply for being German. Postwar youths were faced with an existential either/or decision, that is, either to adopt a new, post-national (perhaps European) 
identity and dissociate themselves entirely from their parents' and grandparents' generations, or, to salvage an identity of the "good German" that enjoyed some continuity with the pre-Nazi past. Moses calls these two potential response types, respectively, the "Non-German German" and the "German German," in an adaptation of Isaac Deutscher's paradigm of the "Non-Jewish Jew" (and its unspoken antonym, the particularistic or nationalist "Jewish Jew"). According to Moses, one's type depended on an "iron logic": "To the extent that one attributed [Nazism's] causes to particularly German characteristics, one was forced to reconfigure one's identity in Non-German German terms by effecting a radical break with inherited traditions. By contrast, to the extent that one felt. . . that the causes were generally modern and European as well as German, it was possible to distinguish Germans from Nazis and therefore feel more comfortable with the continuity of [former Nazi] personnel into the new regime" (p. 109). In other words, the logic dictated that those who believed that the German cultural tradition was irrevocably damaged developed post-national identities, while those who believed in its salvageability retained a recognizably pre-Nazi German self-conception.

As the above quotation demonstrates, Moses sees a direct correspondence between national identity and political orientation in the Federal Republic. He informs readers from the outset that throughout the book he will "refer to NonGerman Germans as 'redemptive republicans' and leftists, and German Germans as 'integrative republicans' and conservatives" (p. 5). The dialectical pair, "redemptive" and "integrative" republicanism, is what Moses has coined as the political discursive analogue to Non-German and German Germanism. Redemptive republicans, he holds, not only managed their stigma problem by inventing cosmopolitan identities for themselves, they also "demanded the moral rehabilitation of the group" (p. 30); they wanted the entire country to become non-German Germans like them. Their goal was patricide: a thorough denazification in the civil service, and a cultural revolution that would have eviscerated Germany's intellectual traditions of all their German particularism. Judging by Moses's examples, it seems that the redemptive republicans generally held a socialist political orientation as well and were therefore critics of Konrad Adenauer's Christian Democratic government. Integrative republicans, on the other hand, as the appellation indicates, were the thinkers who provided the theoretical foundations for Chancellor Adenauer's policy of "reintegration" for both former Nazi personnel and the pre-Nazi cultural tradition. Such thinkers, like Hennis, survived 1945 with their German identities in tact and believed that those older conservative Germans who had supported Nazism, like his mentor Rudolf Smend and even the Nazi "crown jurist" Carl Schmitt, retained enough "good German" in them to participate in the reconstruction of liberal democracy. The "languages of republicanism," redemptive and integrative, competed for prominence up until the 1990s, Moses shows, and never resulted in a value consensus among Germans. "In one political language [redemptive], a republican foundation entails a cathartic break with a deemed evil past," he writes. "In the rival political language, the promulgation of a republican constitution and the establishment of democratic institutions suffice" (p. 41).

These terms, as long as they are nuanced, should prove highly valuable for the orientation of future discussions on West German intellectual history. As all his work has shown, including his careful and trenchant analyses of genocide historiography, 
Moses possesses an uncanny talent for surveying broad and complex tracks of material and perceiving in them the most pressing underlying patterns. Only rarely does he miss the trees for the forest, and then by only a little. The structure of German Intellectuals and the Nazi Past, namely its focus on the "big picture," necessitates a compromise on sustained attention given to individual figures. Thus certain thinkers are at times plotted in confusing ways along the ideological spectrum that spans the joint poles of Non-German and German Germanism, redemptive and integrative republicanism, and left and right.

Take, for example, Moses's treatment of Karl Jaspers. Despite his conservatism, the philosopher is cast as a "non-German German" and "redemptive republican" because of "his existentialist and Protestant categories of 'conversion' (Umkehr), which the young Habermas shared," as well as his critique in 1965 of West Germany's failure "to recognize the fundamental criminality of the Nazi regime by continuing to rehabilitate elements of prewar German culture" (p. 179). However, it is not noted that this was the same Jaspers who, as Stephen Remy points out in The Heidelberg Myth (2002), criticized American-led denazification as over-zealous, resisted university reform, and recommended that Martin Heidegger be barred from teaching only "for several years." Meanwhile, Karl Dietrich Bracher and Kurt Sontheimer are placed into the integrative (and consequently the German German) camp because, as liberals, "they affirmed the foundation of the state in 1949 and wanted the population to live up to its standards" (p. 115). But these political scientists were also uncompromising critics of postwar German nationalism and Adenauer's integration policy, as well as fierce advocates of American social science. Moses neglects to tell us which continuities in German thought they were interested in preserving, aside from a vaguely defined liberalism. Part of the problem here is simply that national identity and political ideology did not always map perfectly onto one another. Moses's approach, illuminating as it is, does not sufficiently acknowledge the fact that the formation of political ideas is often a far messier business, whose logic is almost never ironclad. Some of the thinkers in his study appear to have used the languages of both redemptive and integrative republicanism and adopted identities of the Non-German German and the German German at varying points in their careers and in different perlocutionary contexts.

This takes nothing away from the overall merits of a book that more than makes up for its minor inconsistencies with the opportunities it gives future scholars to explore the gray areas. Studies of particular West German political programs, from foreign policy to political education, will benefit from Moses's framework. His uncovering of a basic structure of German memory discourse should also provide impetus for more work on postwar efforts to rid German intellectual culture of socalled dangerous elements such as nihilism and positivism, as well as on counterefforts to preserve those elements. More attention could be paid to the pre-war origins of "Non-German German" identities and "redemptive republicanism," perhaps in the cosmopolitan left wing of the Social Democratic Party, or in the work of certain German-Jewish thinkers in the Weimar period. Not for nothing were the '68ers - the ultimate Non-German Germans, as Moses shows - so fond of prewar German-Jewish thought, not necessarily out of philosemitism but because of the kind of post-national identity it stood for. There is also a surprising lack of female voices in Moses's work. Future scholarship must fill this gap. 
Perhaps most important, German Intellectuals and the Nazi Past refers us back to the significance of social psychology for the study of political ideas. The reminder is a necessary one, ever since a backlash in the 1980s and 1990s against the muchmaligned psychohistory of the 1970s has made most historians tentative about venturing back into that supposedly "non-scientific" territory. But here be no dragons; on the contrary, we need more scholars like Moses, who are as well versed in Karl Mannheim as they are in Erik Erikson and Cathy Caruth. What we need is not psychohistory, but an interdisciplinary intellectual history that is alive to what Moses calls "political emotions."

One of Moses's boldest, and in my view most incisive, contributions to an interdisciplinary approach is his shifting of the historiographical focus on guilt and shame in postwar Germany to one on stigma. Needless to say, the implication here that Germans would not have been as interested in confronting their recent past, not to mention in finding a republican consensus, without the salutary gaze of the world press might be a hard pill to swallow. However, they will be hard-pressed, I think, to disprove Moses's compelling argument that the traumatic experience of stigmatization under the gaze of non-Germans, with their constant talk of German collective guilt, was decisive in the construction of the political identities of individual young Germans. For guilt is rarely a productive emotion in politics, but shame and indignation - the primary emotional products of stigma - certainly are.

As Moses points out in his conclusion, only very recently-probably within this decade - have Germans stopped feeling the constant scrutinizing gaze of the Western world as they go about their daily politics. The American senator Barack Obama, in his 2008 speech in front of a classic symbol of Prussian military might, the Siegessäule, on the anniversary of the Berlin Airlift, made not one reference to Germany's Nazi past. After more than 60 years of collective stigmatization, Germany's leading intellectuals now have enough moral leverage on the world stage and sufficient confidence in their own institutions to criticize the United States and even Israel without fearing accusations from international watchdogs on the lookout for any sign of German recidivism. When one American historian recently called upon an audience of German intellectuals to recognize their country's historical responsibility to combat the anti-Zionist regime in Iran, he met with almost unanimous resistance. "Germany has changed," he complained. Indeed, it has. Moses welcomes this "normalization" as salutatory. Three or four generations after the Holocaust, the moral stain of the Nazi past that structured early debates on politics in the Federal Republic has significantly faded from public discourse, and "younger Germans are no longer vulnerable to such attempts to revive German stigma in the service of partisan geopolitics" (p. 283).

This is not to say that the stain has disappeared, or that Germany has mastered what is arguably an unmasterable past. Moses explicitly takes aim, and with good reason, at the "whiggish" historians of the Federal Republic, according to whom "the twenty-first century marked the culmination of a collective moral learning process for Germany" (p. 5). Such a self-satisfied, and in its worst incarnations theodicean, interpretation of postwar German history neglects the fact that no consensus about the meaning and memory of the Nazi past has ever been reached, and perhaps more important, neglects the fact that many intellectuals in early Federal Republic denied the necessity of a "collective moral learning process" in the first place. Moses's 
greatest contribution in German Intellectuals and the Nazi Past is his analysis of why some intellectuals believed that the German population needed to be morally transformed after the war and why others did not. One looks forward eagerly to what uncharted territory Moses will explore next.

Open Access This article is distributed under the terms of the Creative Commons Attribution Noncommercial License which permits any noncommercial use, distribution, and reproduction in any medium, provided the original author(s) and source are credited.

Noah Strote is a Ph.D. candidate in the Department of History at the University of California, Berkeley. $\mathrm{He}$ is currently writing his dissertation on re-education and the return of refugee intellectuals to postwar Germany. 